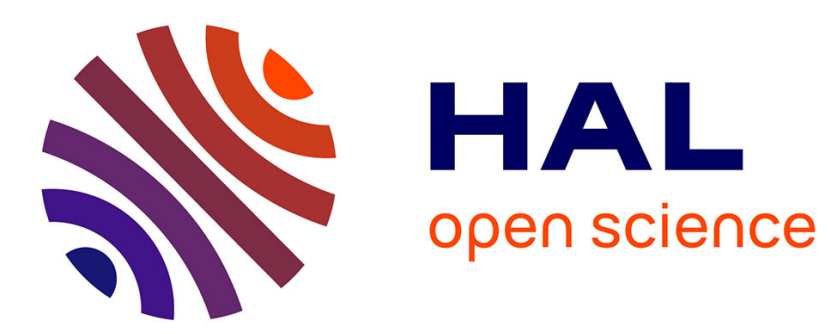

\title{
Structural characterisation of trimethylsilyl-protected DNA bases
}

Kieran Molloy, Gareth Price, Doug Smith, Gabriele Kociok-Khön

\section{To cite this version:}

Kieran Molloy, Gareth Price, Doug Smith, Gabriele Kociok-Khön. Structural characterisation of trimethylsilyl-protected DNA bases. Supramolecular Chemistry, 2008, 20 (08), pp.697-707. 10.1080/10610270701732885 . hal-00513518

\section{HAL Id: hal-00513518 \\ https://hal.science/hal-00513518}

Submitted on 1 Sep 2010

HAL is a multi-disciplinary open access archive for the deposit and dissemination of scientific research documents, whether they are published or not. The documents may come from teaching and research institutions in France or abroad, or from public or private research centers.
L'archive ouverte pluridisciplinaire HAL, est destinée au dépôt et à la diffusion de documents scientifiques de niveau recherche, publiés ou non, émanant des établissements d'enseignement et de recherche français ou étrangers, des laboratoires publics ou privés. 


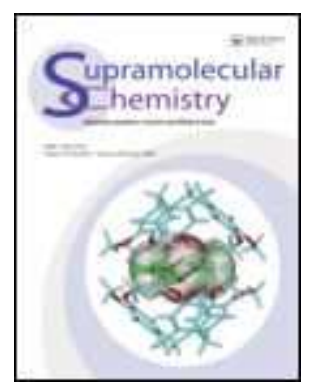

\section{Structural characterisation of trimethylsilyl-protected DNA bases}

\begin{tabular}{|c|c|}
\hline Journal: & Supramolecular Chemistry \\
\hline Manuscript ID: & GSCH-2007-0133.R1 \\
\hline Manuscript Type: & Full Paper \\
\hline $\begin{array}{r}\text { Date Submitted by the } \\
\text { Author: }\end{array}$ & $05-O c t-2007$ \\
\hline Complete List of Authors: & $\begin{array}{l}\text { Molloy, Kieran; University of Bath, Chemistry } \\
\text { Price, Gareth; University of Bath, Chemistry } \\
\text { Smith, Doug; University of Bath, Chemistry } \\
\text { Kociok-Khön, Gabriele; University of Bath, Chemistry }\end{array}$ \\
\hline Keywords: & silylated DNA bases, adenine, guanine, cytosine, thymine \\
\hline
\end{tabular}

\section{(s) ScholaroNE* \\ Manuscript Central}




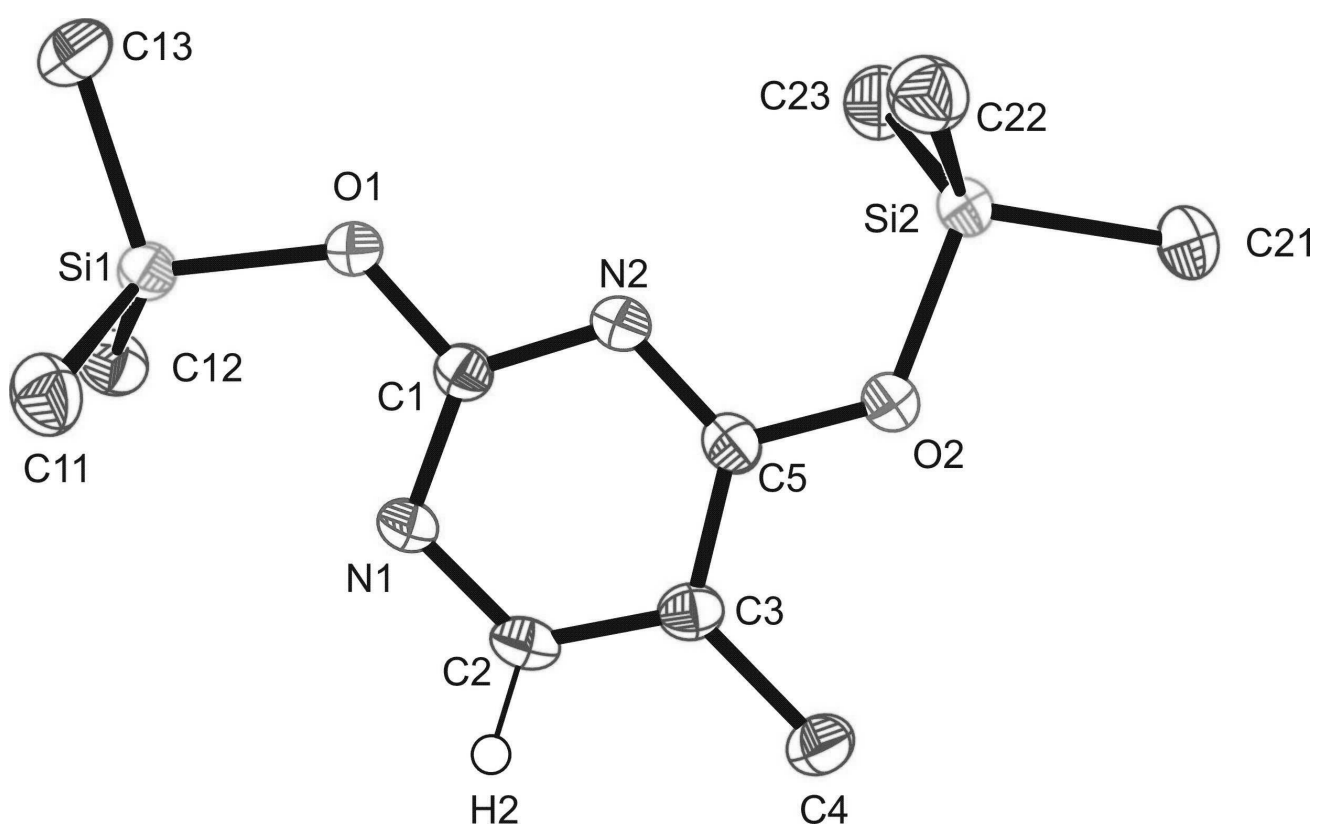

Figure 1 . The asymmetric unit of 1 ; ellipsoids are at the $50 \%$ probability level. Hydrogen atoms of the Me3Si groups omitted for clarity. $210 \times 129 \mathrm{~mm}(300 \times 300 \mathrm{DPI})$ 


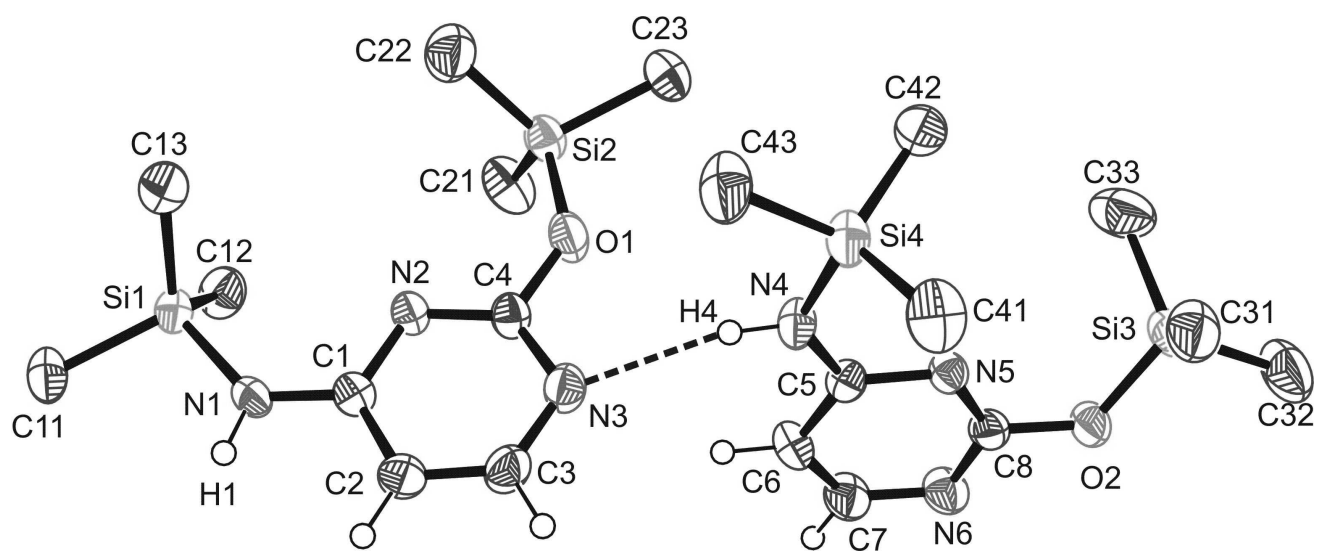

Figure 2. The asymmetric unit of 2 ; ellipsoids are at the $50 \%$ probability level. Hydrogen atoms of the Me3Si groups omitted for clarity. $262 \times 107 \mathrm{~mm}(300 \times 300 \mathrm{DPI})$ 
Figure 3 The helical chain structure of 2 viewed (a) orthogonal to, and (b) along the axis of propagation (c); Symmetry operator $3 / 2-x, 1-y, 1 / 2+z$. $444 \times 329 \mathrm{~mm}(96 \times 96 \mathrm{DPI})$ 


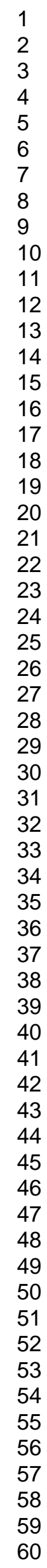

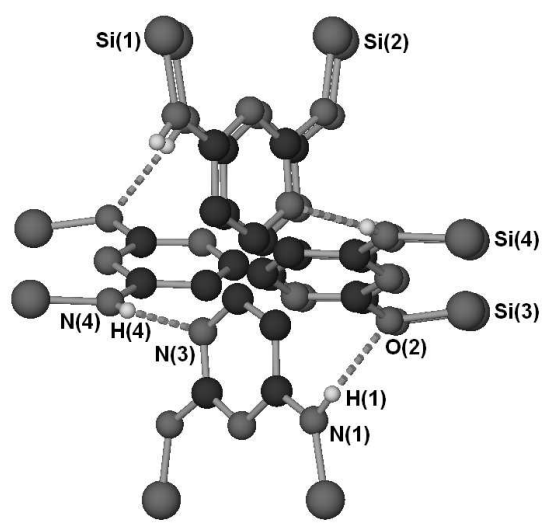

$444 \times 329 \mathrm{~mm}(96 \times 96 \mathrm{DPI})$ 


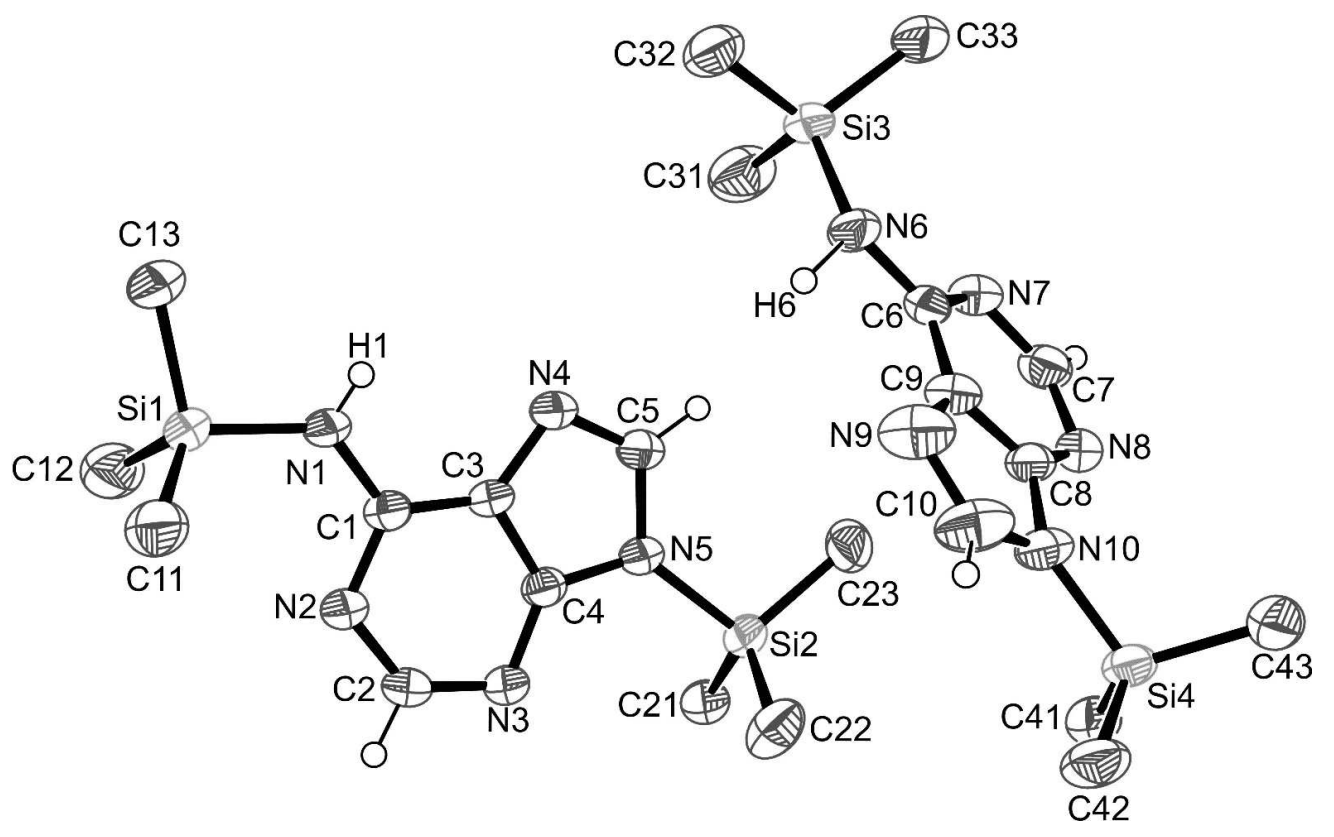

Figure 4 The asymmetric unit of 3 showing the two independent molecules in the asymmetric unit; ellipsoids are at the $50 \%$ probability level. Hydrogen atoms of the Me3Si groups omitted for clarity. Symmetry operator $1-\mathrm{x}, \mathrm{y}, 1 / 2-\mathrm{z}$. $266 \times 164 \mathrm{~mm}(300 \times 300 \mathrm{DPI})$ 
Figure 5 Two views of the dimerisation of one of the independent molecules on the asymmetric unit of 3.

$444 \times 329 \mathrm{~mm}(96 \times 96 \mathrm{DPI})$ 


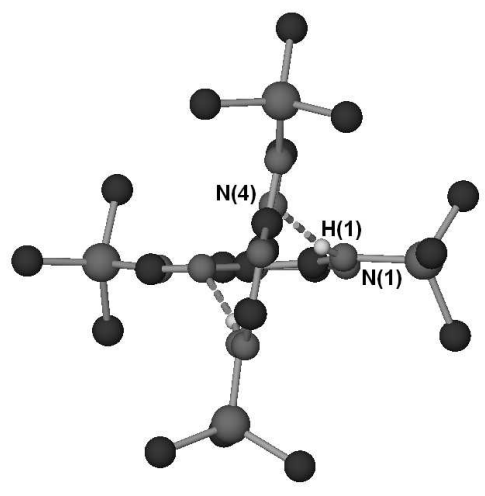

$444 \times 329 \mathrm{~mm}(96 \times 96 \mathrm{DPI})$ 


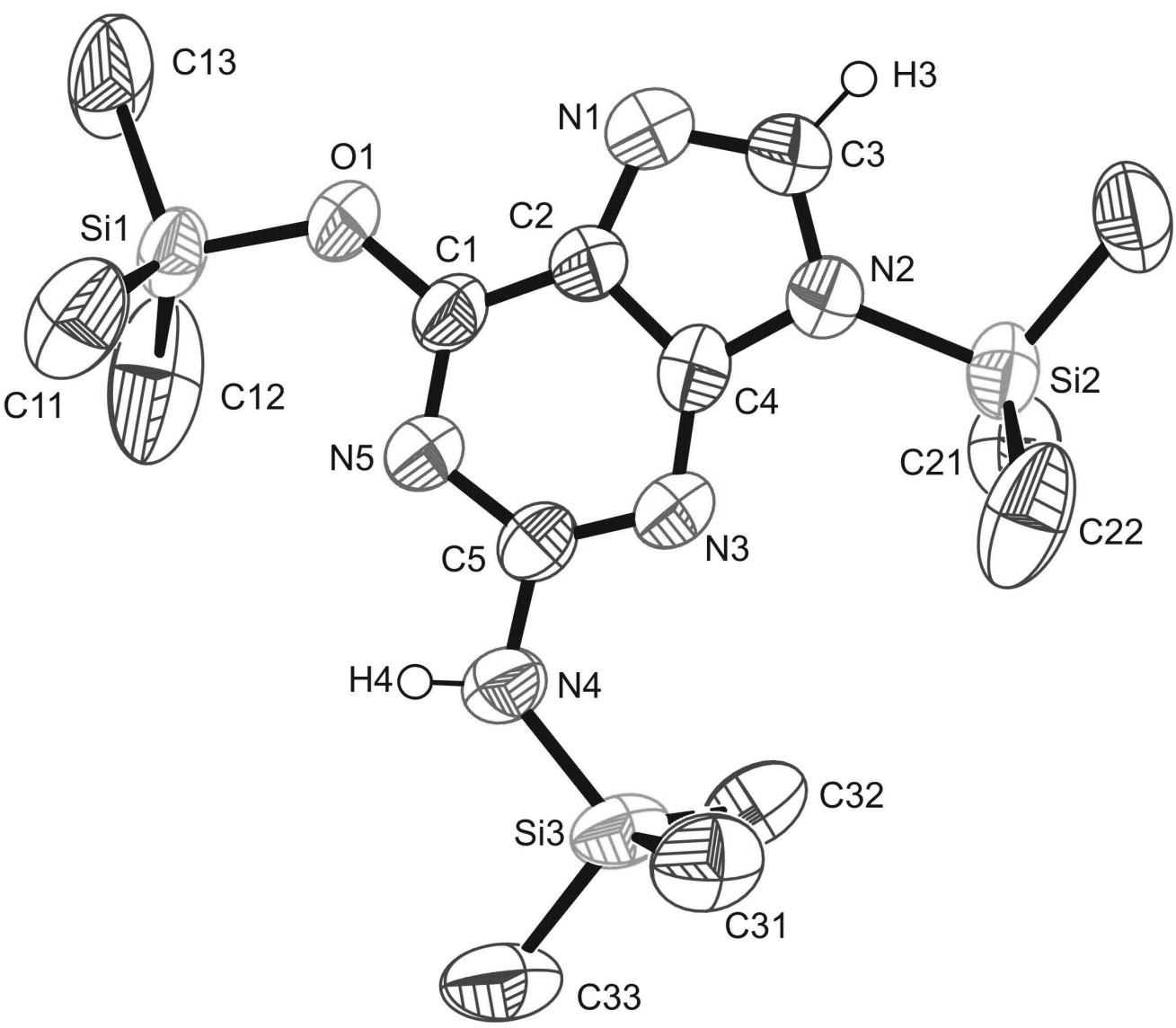

Figure 6 The asymmetric unit of 4; ellipsoids are at the 50\% probability level. Hydrogen atoms of the Me3Si groups omitted for clarity. $196 \times 169 \mathrm{~mm}(300 \times 300 \mathrm{DPI})$ 
Figure 7 The lattice structure of 4 viewed (a) orthogonal to, and (b) along the axis of propagation $444 \times 329 \mathrm{~mm}$ (96 x 96 DPI) 


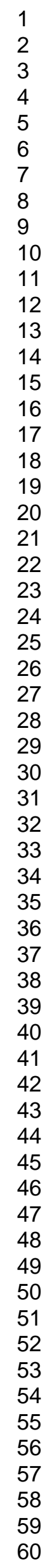

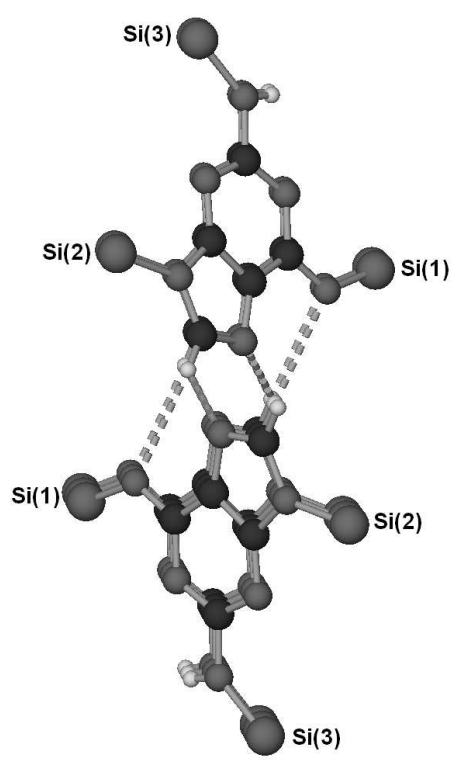

$444 \times 329 \mathrm{~mm}(96 \times 96$ DPI) 
1

2

3

4

5

6

7

8

9

10

11

12

13

14

15

16

17

18

19

20

21

22

23

24

25

26

27

28

29

30

31

32

33

34

35

36

37

38

39

40

41

42

43

44

45

46

47

48

49

50

51

52

53

54

55

56

57

58

59

60

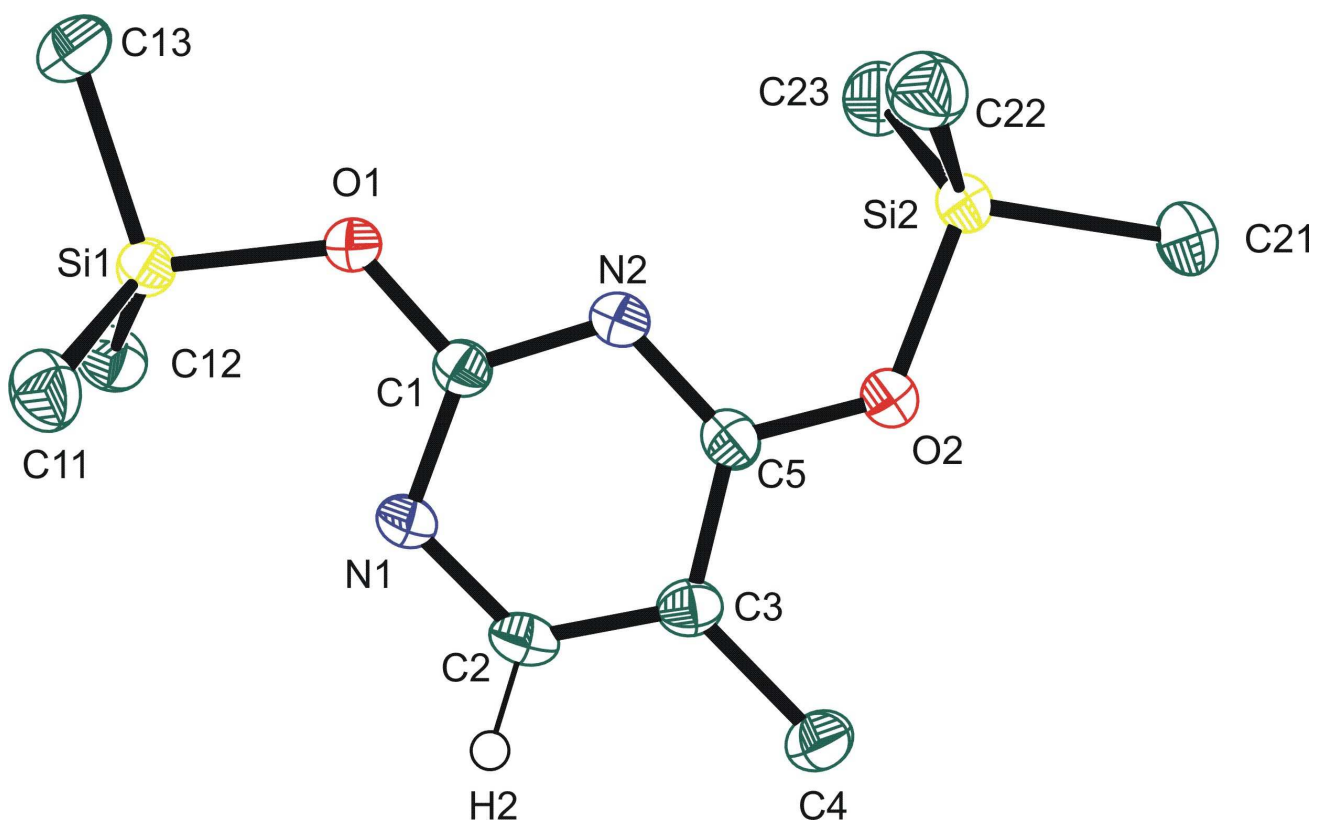

Figure 1 . The asymmetric unit of 1 ; ellipsoids are at the $50 \%$ probability level. Hydrogen atoms of the Me3Si groups omitted for clarity.

$210 \times 129 \mathrm{~mm}(300 \times 300$ DPI $)$ 


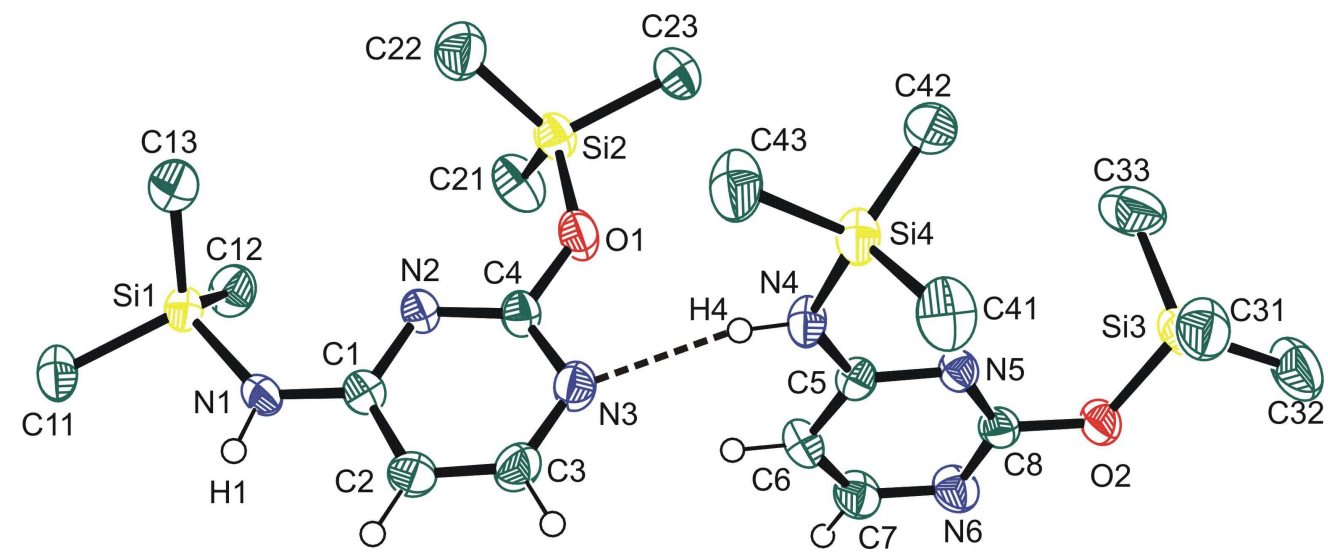

Figure 2. The asymmetric unit of 2; ellipsoids are at the $50 \%$ probability level. Hydrogen atoms of the Me3Si groups omitted for clarity. $262 \times 107 \mathrm{~mm}(300 \times 300 \mathrm{DPI})$ 
Figure 3 The helical chain structure of 2 viewed (a) orthogonal to, and (b) along the axis of propagation (c); Symmetry operator $3 / 2-x, 1-y, 1 / 2+z$. $444 \times 329 \mathrm{~mm}(96 \times 96 \mathrm{DPI})$ 


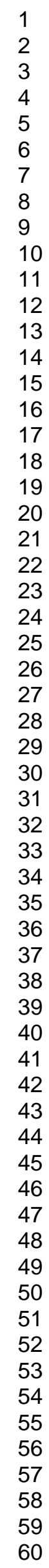

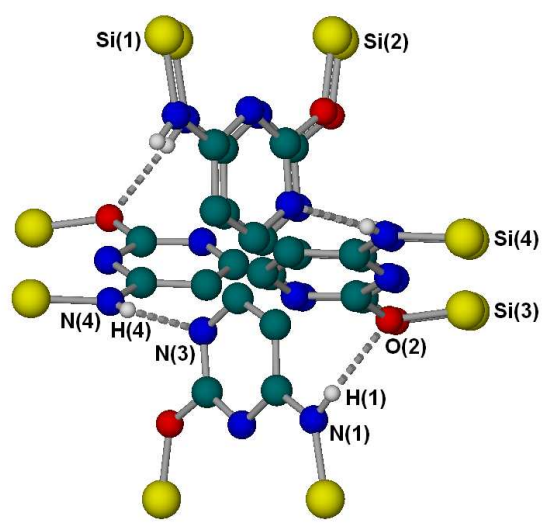

$444 \times 329 \mathrm{~mm}(96 \times 96 \mathrm{DPI})$ 


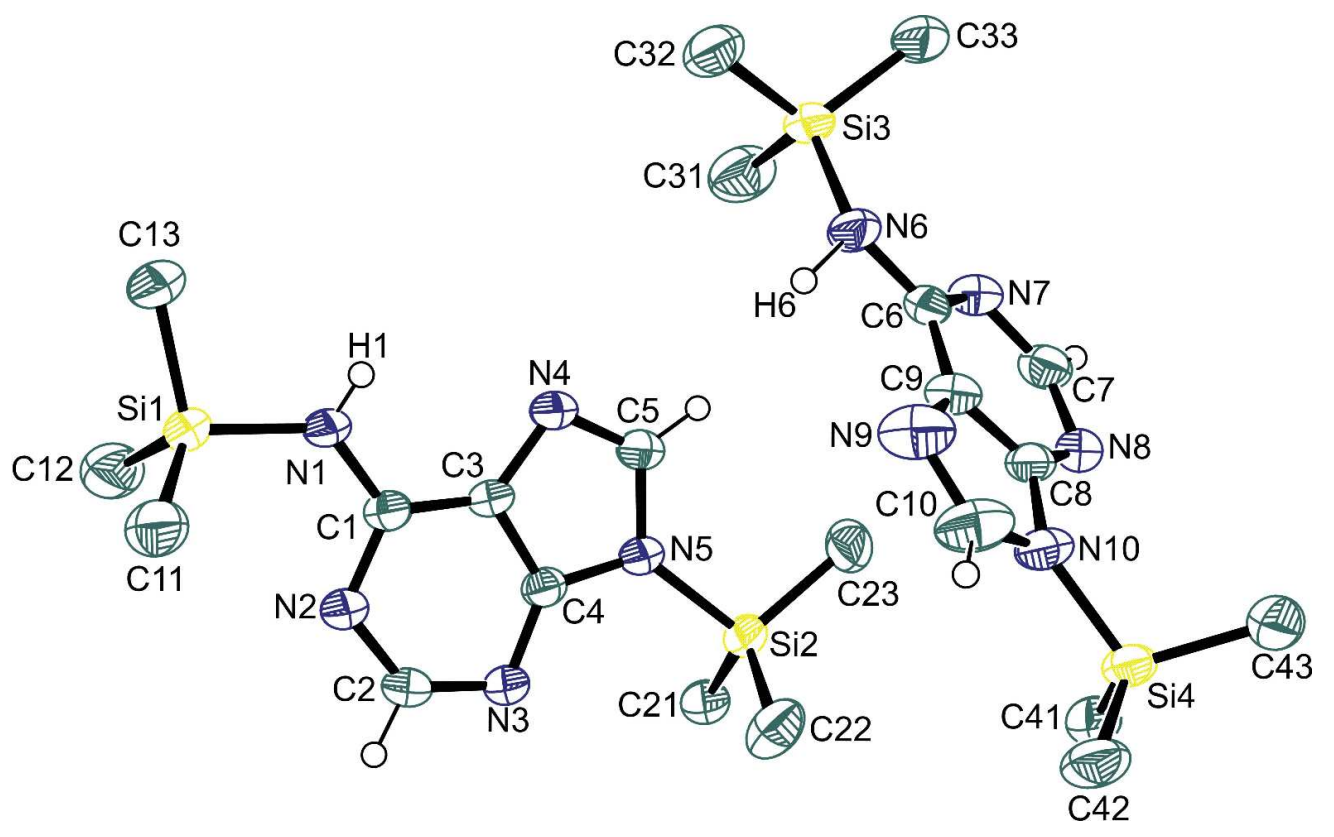

Figure 4 The asymmetric unit of 3 showing the two independent molecules in the asymmetric unit; ellipsoids are at the $50 \%$ probability level. Hydrogen atoms of the Me3Si groups omitted for clarity. Symmetry operator $1-\mathrm{x}, \mathrm{y}, 1 / 2-\mathrm{z}$. $266 \times 164 \mathrm{~mm}(300 \times 300 \mathrm{DPI})$ 
Figure 5 Two views of the dimerisation of one of the independent molecules on the asymmetric unit of 3.

$444 \times 329 \mathrm{~mm}(96 \times 96 \mathrm{DPI})$ 


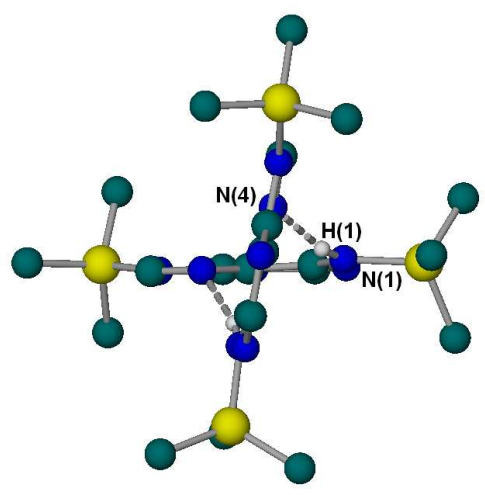

$444 \times 329 \mathrm{~mm}(96 \times 96 \mathrm{DPI})$ 


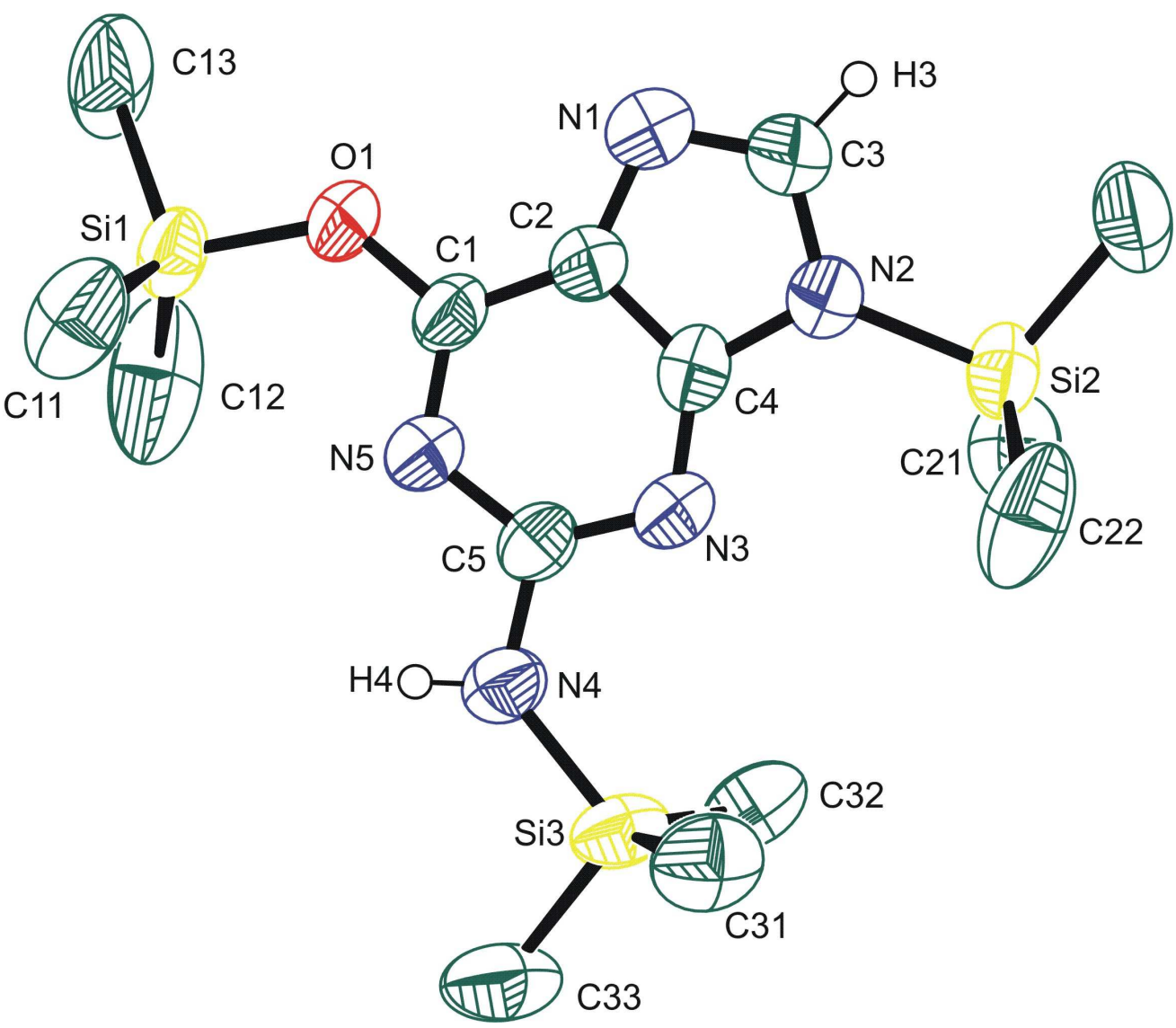

Figure 6 The asymmetric unit of 4; ellipsoids are at the 50\% probability level. Hydrogen atoms of the Me3Si groups omitted for clarity. $196 \times 169 \mathrm{~mm}(300 \times 300 \mathrm{DPI})$ 
Figure 7 The lattice structure of 4 viewed (a) orthogonal to, and (b) along the axis of propagation $444 \times 329 \mathrm{~mm}$ (96 × 96 DPI) 


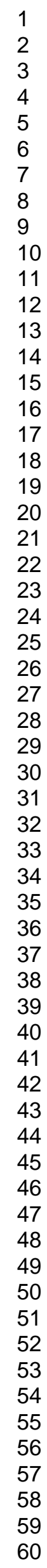

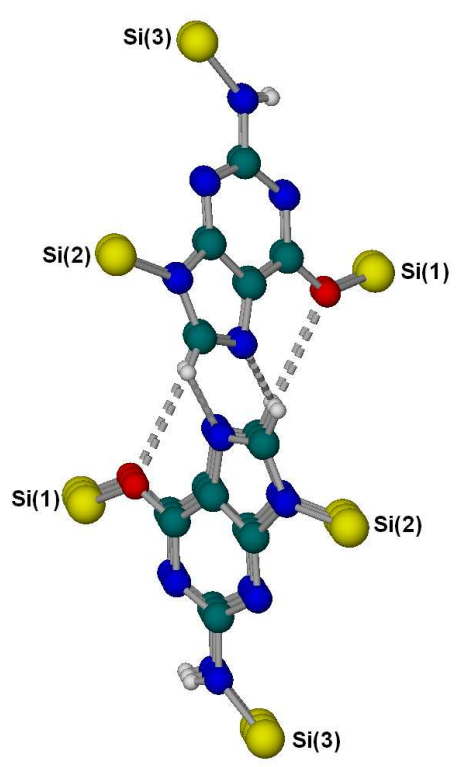

$444 \times 329 \mathrm{~mm}(96 \times 96 \mathrm{DPI})$ 